\title{
OCCURRENCE AND ECOLOGICAL NOTES ON ROCINELA SIGNATA (ISOPODA, FLABELLIFERA) OFF BRAZIL
}

\author{
PLINIO SOARES MOREIRA \\ Instituto Oceanográfico da Universidade de São Paulo
}

\section{SYNOPS IS}

This paper discuss the vertical and horizontal distribution of the marine isopod Rocinela signata Schiödte \& Meinert, 1879, along Brazil. Published records and new data gathered in recent years were used. The species, widely distributed along Brazil, has its most southern limit of occurrence considerably extended to off State of Santa Catarina $\left(27^{\circ} 08^{\prime} \mathrm{S}, 48^{\circ} 11^{\prime} \mathrm{W}\right)$. It is typically a shelf species . So far it was recorded off Brazil at a maximum depth of $73 \mathrm{~m}$, while particularly in southern Brazil at $53 \mathrm{~m}$. The species has been collected free living on the bottom or as a fish parasite, and a few times has been reported attacking and sucking swimmers. Available data suggest any host specificity. $R$. signata seems a facultative and not an obligate fish parasite.

\section{NTRODUCT I ON}

Rocinela signata is a marine isopod readily distinguished from the remaining species of the genus by the characteristic inverted $\mathrm{W}$-shaped pigmented figure on the pleotelson. Since the description of the species by Schiödte \& Meinert in 1879, this character is the main one used for its recognition.

R. signata have been previously recorded from a few Brazilian localities (Moreira, 1971, 1972; Coelho \& Koening, 1972). New material collected in recent years in southern and northern Brazil seems worth-while to be published for a better knowledge of the vertical and horizontal distribution of the species along the Brazilian coast.

PUBL. NO 408 DO INST. OCEAN. DA USP. 


\section{MATERIAL AND METHODS}

Part of the material studied (series MBT) was collected by the author through its ISOTAN-DRAGA I Project. The surveys were performed with the research vessels "Prof. W. Besnard" and "Emília", of the Instituto Oceanográfico of the University of São Paulo. The collecting device employed was the MBT dredge. The remaining of the specimens was provided by colleagues and friends. All specimens were preserved in $70^{\circ}$ alcohol, and examined under a Wild binocular microscope. Literature records were incorporate into the data included in this paper to complete the known distribution of the species along Brazil. By obvious reasons, the "Emília" stations and some specimens localities were positioned accordingly to the latest nautic chart delivered by Diretoria de Hidrografia e Navegação (DHN), of the Brazilian Navy .

\section{RESULTS AND DISCUSSION}

The number of stations, localities of collections, date, depth and other related data on both $R$. signata specimens and their collecting sites are listed in Material Examined.

Figure 1 shows the distribution of the species, based on present data and on previously published ones (Schiödte \& Meinert, 1879; Moreira, 1972; Coelho \& Koening, 1972). It should be remarked that Schiödte \& Meinert (op . cit.) data refer to the occurrence of the species off a given State, and not to the precise location of the samples.

Figure 1 shows that $R$. signata is widely distributed along Brazil. Through its present range of distribution, the species seems absent from certain States probably by lacking of collections. The horizontal distribution of the species is considerably extended southwards, from Santos (SP) to off State of Santa Catarina $\left(27^{\circ} 08^{\prime} \mathrm{S}, 48^{\circ} 11^{\prime} \mathrm{W}\right)$, which is the new most southern limit of its occurrence.

The vertical range of $R$. signata along Brazil extends from shore to $73 \mathrm{~m}$ depth. So far, in northern Brazil the maximum depth of occurrence of the species is $73 \mathrm{~m}$, while in southern Brazil it is $50 \mathrm{~m}$. This occurrence is its 


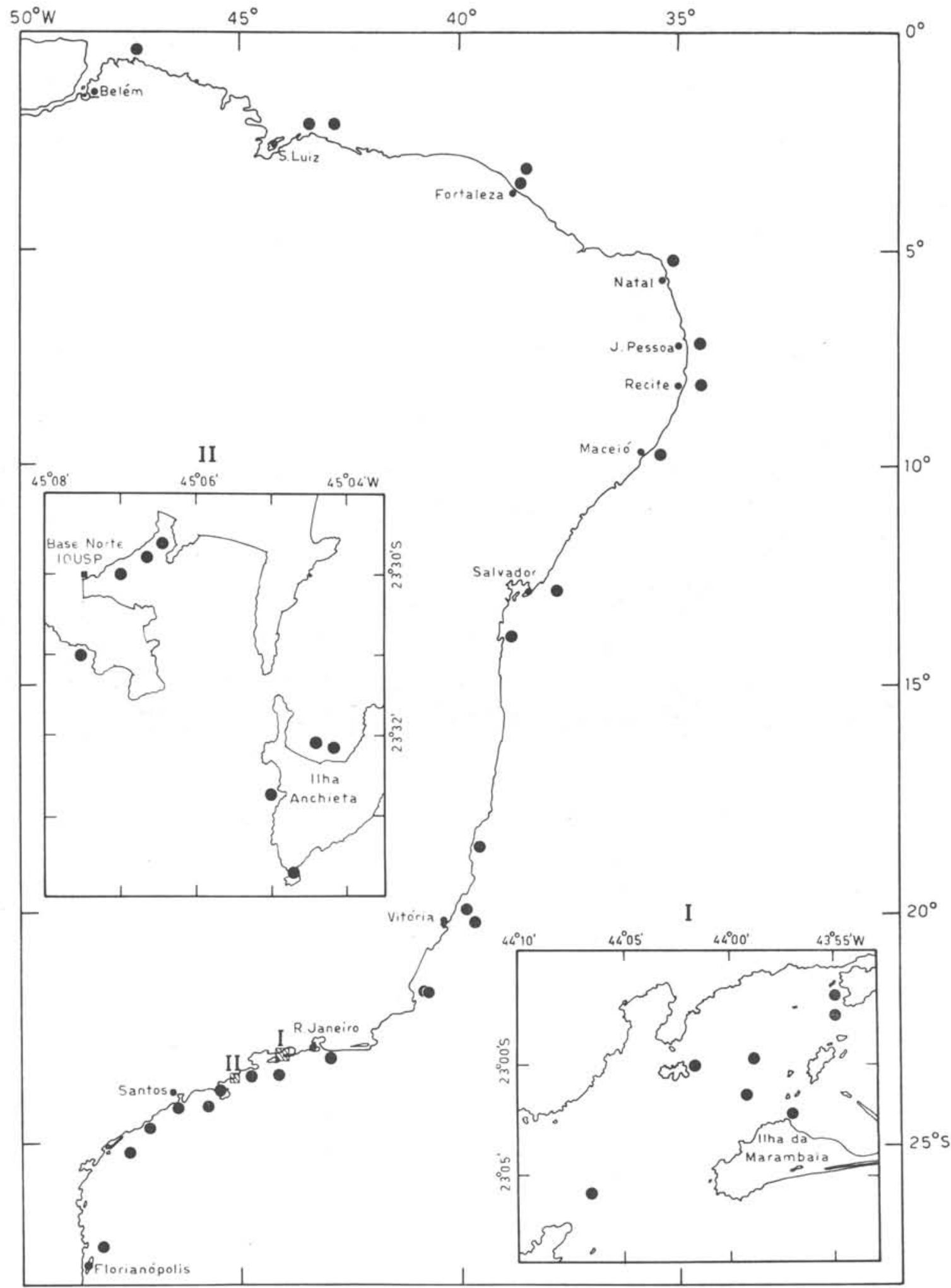

Fig. 1 - Geographical distribution of Rocinela signata Schiödte \& Meinert, along Brazil, based on published and present original data. 
new maximum recorded depth in southern Brazil. The species seems a typically shelf species.

As previously remarked (Moreira, 1972), also in the present material mostly of the specimens were gathered living free on the bottom. These specimens seldonly show visible vestiges of ingested blood. However, all those animals collected on fishes have the gut filled with a large dark-reddish mass of ingested blood, which makes their gut and ventral pereonal body wall strongly distended, prominent and smooth. Animals with ingested blood found free either amongst otter-traw1 fishes and crabs, or collected on the bottom by dredging, most probably become detached recently from their host. Possibly the species only at times behavies as a blood-sucking ectoparasite, since the number of animals collected living free on the bottom apparently indicate that they are also able to live when not attached to the host.

In spite of the large number of fish species/specimens examined for the occurrence of parasite isopods, so far only few specimens of $R$. signata were found attached to them. Moreira $(1971,1972)$ reported $R$. signata in two species of fishes, namely, "pescada-branca" (Cynoscion leiarchus) and "pescada-amarela" (Cynoscion acoupa).

In the present collection the species is reported on the gills of "cioba" (Lutjanus conalis) and "cabrinha" (Prionotus sp.). Schiödte \& Meinert (1879); Richardson (1905) and Menzies \& Glynn (1968) recorded it on some Teleostei and Chondrichthyes fish species. Moreira (1971, 1972 and present paper) reports the species attacking and bitting swimmers.

However, as $R$. signata have mostly been collected living free on the bottom, and sparingly on different fish species, it seems reasonable to consider it as a facultative and not an obligate fish parasite. Literature data on records of $R$. signata, in spite of scanty, seems to support this. These same data also suggest any host specificity, since the species until now have been collected from at least 6 or 7 different species of fish.

\section{RESUMO}

0 presente trabalho discute especialmente a distribuição vertical e horizontal do isópode marinho Rocinela signata Schiödte \& Meinert, 1879, ao 
longo do Brasil. Utilizou-se, para tanto, de dados publicados e outros originais, estes obtidos nos últimos anos. A espécie apresenta ampla distribuição ao largo do Brasil, sendo sua ocorrência mais meridional ampliada até - Estado de Santa Catarina $\left(27^{\circ} 08^{\prime} \mathrm{S}, 48^{\circ} 11^{\prime} \mathrm{W}\right)$. A espécie é típica de plataforma continental, tendo sido registrada ao longo do Brasil, até o presente, a uma profundidade máxima de $73 \mathrm{~m}$, porém na região centro-sul a $53 \mathrm{~m}$. $R$. signata tem sido coletada livremente sobre o substrato ou como ectoparasita de peixes, e algumas vezes atacando e sugando o sangue de banhistas. Dados publicados indicam não haver especificidade de hospedeiro. A espécie pode ser considerada como um parasita facultativo e não como um parasita obrigatório de peixes.

\section{ACKNOWLEDGEMENTS}

The author thanks all colleagues and friends which provided part of the material studied, namely, Drs. E. Nonato, Luiz R. Tommasi and H. Nomura, M. Sc. José Carlos de Freitas, Messrs. Clarimundo de Jesus, M. Furuya and Roberto Galvão.

\section{MATERIAL EXAMINED}

\section{STATE OF MARANHÃO}

1. São Luiz. Praia da Ponta da Areia. January/1971. José Carlos de Freitas leg. Specimens gathered attached to the collector's legs during a beach trip; the removal of the parasite caused bleeding. 2 young females 6.5 and $10.8 \mathrm{~mm}$ long without oostegites, and gut filled with a dark-reddish mass of ingested blood.

\section{STATE OF CEARÁ}

2. Fortaleza. May/1965. H. Nomura 1eg. On the gills of "cioba" (Lutjanus analis). 2 young females $11.2 \mathrm{~mm}$ long without oostegites, and gut filled with a large reddish mass of ingested blood. 


\section{STATE OF BAHIA}

3. Enseada de Camamu, about $13^{\circ} 53^{\prime} \mathrm{S}, 39^{\circ} 01^{\prime} \mathrm{W}$. August $/ 1973.6 \mathrm{~m}$ depth. Roberto Galvão leg. Amongst fishes and crabs. 1 young female $11.1 \mathrm{~mm}$ long deprived of both oostegites, and mass of ingested blood.

\section{STATE OF ESPIRITO SANTO}

4. Off Rio São Mateus. $18^{\circ} 31.2^{\prime} \mathrm{S}, 39^{\circ} 41.8^{\prime} \mathrm{W}$. July $/ 1972.24 .53^{\circ} \mathrm{C} .36 .10 \mathrm{~S} \%$ $14 \mathrm{~m}$ depth. Oc/S "Prof. W. Besnard". van Veen 1/10. P. S. Moreira col. 1 juvenile $6.0 \mathrm{~mm}$ long with developing pereopod VII, and gut without mass of ingested blood.

5. Off Rio Santa Cruz. $19^{\circ} 59^{\prime} \mathrm{S}, 39^{\circ} 56^{\prime} \mathrm{W}$. July/1972. $21.62^{\circ} \mathrm{C} .36 .57 \mathrm{~S}^{\circ} / \mathrm{oo}$. $4.13 \mathrm{ml} / \mathrm{O}_{2}$. $41 \mathrm{~m}$ depth. Oc/S "Prof. W. Besnard". van Veen 1/10. P. S. Moreira col. 1 juvenile $3.2 \mathrm{~mm}$ long deprived of pereopod VII, and gut without mass of ingested blood.

6. Ilha da Trindade, far off Brazilian coast, about $20^{\circ} 30^{\prime} \mathrm{S}, 29^{\circ} 30^{\prime} \mathrm{W}$. May/ 1950. $40 \mathrm{~m}$ depth. Otter-trawl. Wladimir Besnard leg. Amongst fishes and crabs. 1 adult female $15.1 \mathrm{~mm}$ long without oostegites, and gut filled with a reddish mass of ingested blood.

\section{STATE OF RIO DE JANEIRO}

7. Off Cabo de São Tomé. $21^{\circ} 46^{\prime} \mathrm{S}, 40^{\circ} 56^{\prime} \mathrm{W}$. November $/ 1970.16 \mathrm{~m}$ depth. Oc/S "Prof. W. Besnard". Beam-traw1. P. S. Moreira col. MBT series. 1 young female $12.8 \mathrm{~mm}$ long without oostegites and mass of ingested blood.

8. Off Cabo de São Tomé. $21^{\circ} 46^{\prime} \mathrm{S}, 40^{\circ} 58^{\prime} \mathrm{W}$. November $/ 1970 \cdot 20.03^{\circ} \mathrm{C} \cdot 36.20 \mathrm{~s} \%$ oo $15 \mathrm{~m}$ depth. Oc/s "Prof. W. Besnard". MBT dredge. P. S. Moreira col. MBT series. 1 young female $7.8 \mathrm{~mm}$ long without both oostegites, and mass of ingested blood.

9. Off Baía de Guanabara. $23^{\circ} 02^{\prime} \mathrm{S}, 43^{\circ} 00^{\prime} \mathrm{W}$. November $/ 1970.15 .55^{\circ} \mathrm{C} .35 .68$ S\%/oo. $4.89 \mathrm{ml} / \mathrm{O}_{2} .40 \mathrm{~m}$ depth. Oc/S "Prof.W. Besnard". MBT dredge. P. S. Moreira col. MBT series. 1 young female $8.1 \mathrm{~mm}$ long without both oostegites, and reddish mass of ingested blood. 
10. Off Ilha Grande. $23^{\circ} 14^{\prime} \mathrm{S}, 4^{\circ} 03^{\prime} \mathrm{W}$. June/1971. $52 \mathrm{~m}$ depth. Oc/S "Prof. W. Besnard". MBT dredge. P.S. Moreira col. MBT series. 1 young female $7.5 \mathrm{~mm}$ long without both oostegites, and mass of ingested blood.

11. Off Ilha de Itacurussá, about $22^{\circ} 58^{\prime} \mathrm{S}, 43^{\circ} 55^{\prime} \mathrm{W}$. July/1966. $22.54^{\circ} \mathrm{C}$. $33.60 \mathrm{~S} \%$ oo. $25 \mathrm{~m}$ depth. R/V "Emília". Rectangular dredge. Luiz R. Tommasi leg. 1 adult female $13.1 \mathrm{~mm}$ long without oostegites, and gut filled with a large reddish mass of ingested blood.

12. Off Ilha de Marambäia, about $22^{\circ} 59^{\prime} 45^{\prime \prime S}, 43^{\circ} 59^{\prime} \mathrm{W}$. March/1969. $26.70^{\circ} \mathrm{C}$. $33.40 \mathrm{~S} \%$ oo. $9 \mathrm{~m}$ depth. R/V "Emília". Rectangular dredge. Luiz R. Tommasi leg. 1 juvenile $6.3 \mathrm{~mm}$ long with developing pereopod VII, and gut without mass of ingested blood.

13. Off Ilha Guaiba, about $23^{\circ} 00^{\prime} 15^{\prime \prime} \mathrm{S}, 4^{\circ} 01^{\prime} 30^{\prime} \mathrm{W}$. June $/ 1967 \cdot 22.10^{\circ} \mathrm{C} \cdot 34.22$ $\mathrm{S} \%$ oo. $10 \mathrm{~m}$ depth. R/V "Emília". van Veen 1/10. Luiz R. Tommasi leg. 1 ovigerous female $13.0 \mathrm{~mm}$ long.

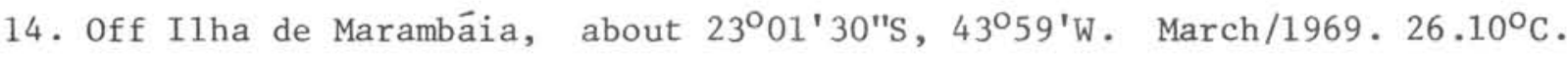
$32.80 \mathrm{~s} \%$ o . $10 \mathrm{~m}$ depth. R/V "Emília". Rectangular dredge. Luiz R. Tommasi leg. 1 ovigerous female $13.0 \mathrm{~mm}$ long.

15. Baía de Marambaía, about $23^{\circ} 02^{\prime} \mathrm{S}, 43^{\circ} 57^{\prime} \mathrm{W}$. December $/ 1970.7 \mathrm{~m}$ depth. R/V "Emília". van Veen 1/10. Luiz R. Tommasi leg. 1 young female $6.1 \mathrm{~mm}$ long without both oostegites, and reddish mass of ingested blood.

16. Ilha Grande. Off Ponta Grossa, about $23^{\circ} 05^{\prime} \mathrm{s}, 44^{\circ} 03^{\prime} \mathrm{W}$. February $/ 1968$. $20 \mathrm{~m}$ depth. Oc/s "Prof. W. Besnard". Photograb. Clarimundo de Jesus leg. 1 fragment of the posterior part of the body of an adult female.

\section{STATE OF SÃO PAULO}

17. Ubatuba. Enseada do Flamengo, praia do Lamberto, at the pier of Base Norte $\left(23^{\circ} 30^{\prime} \mathrm{s}, 45^{\circ} 07^{\prime} \mathrm{W}\right)$ of the Instituto Oceanográfico, USP. Octuber/ 1968. Superficial night plankton using a light as a lure. Local depth: $2 \mathrm{~m}$. E. Nonato $1 \mathrm{eg} .1$ young female $6.3 \mathrm{~mm}$ long without both oostegites, and mass of ingested blood; 1 juvenile $5.0 \mathrm{~mm}$ long deprived of pereopod VII, and gut without mass of ingested blood. 
18. Off I1ha dos Alcatrazes. $24^{\circ} 03^{\prime} \mathrm{S}, 45^{\circ} 40^{\prime} \mathrm{W}$. March $/ 1969.35 \mathrm{~m}$ depth. R/V "Emília". Otter-trawl. P. S. Moreira col. 1 young male $11.5 \mathrm{~mm}$ long bearing developing copulatory process, and gut filled with a reddish mass of ingested blood.

19. Off Ponta da Juréia. $24^{\circ} 36^{\prime} \mathrm{S}, 47^{\circ} 07^{\prime} \mathrm{W}$. June $/ 1970.16 .65^{\circ} \mathrm{C} .35 .67 \mathrm{~S} / \mathrm{oo}$. $21 \mathrm{~m}$ depth. 0c/s "Prof. W. Besnard". MBT dredge. P. S. Moreira col. MBT series. 1 young female $8.0 \mathrm{~mm}$ long without both oostegites, and mass of ingested blood in the gut.

20. Off Ilha do Bom Abrigo. 25013's, 47029'w. June/1970. $32 \mathrm{~m}$ depth. Oc/s "Prof. W. Besnard". MBT dredge. P. S. Moreira col. MBT series. 1 young female $12.0 \mathrm{~mm}$ long without both oostegites, and mass of ingested blood in the gut.

\section{STATE OF SANTA CATARINA}

21. Off Ilha do Arvoredo. $27^{\circ} 08^{\prime} \mathrm{S}, 48^{\circ} 11^{\prime} \mathrm{W}$. January/1957. $50 \mathrm{~m}$ depth. Oc/S "Toko Maru". Otter-traw1. M. Furuya leg. On the gills of "cabrinha" (Prionotus sp.). 1 juvenile $6.5 \mathrm{~mm}$ long with developing pereopod VII, and gut filled with a reddish mass of ingested blood.

\section{REFERENCES}

COELHO, P. A. \& KOENING, M. L. 1972. A distribuição dos crustáceos pertencentes às ordens Stomatopoda, Tanaidacea e Isopoda no Norte e Nordeste do Brasil. Trabhs Oceanogr. Univ. Fed. Pe., Recife, 13:245-260.

MENZIES, R. J. \& GLYNN, P. W. 1968. The common marine isopod Crustacea of Puerto Rico. Stud. Fauna Curaçao, 27:1-133.

MOREIRA, P. S. 1971. Sobre Rocinela signata Schiödte \& Meinert, 1879 (Isopoda, Flabellifera). Ciênc. Cult., S Paulo, 23(supp1.):389.

1972. Species of marine Isopoda (Crustacea, Peracarida) from southern Brazil. Bolm Inst. oceanogr., S Paulo, 21:163-179.

RICHARDSON, H. 1905. A monograph on the isopods of North America. Bul1. U. S. natn. Mus., 54:i-xxv, 1-727. 
SCHIÖDTE, J. C. \& MEINERT, FR. 1879. Symbolae ad Monographiam Cymothoarum Crustaceorum Isopodum Familiae. Naturh. Tidsskr., 12:321-415, p1s. 7-13.

(Received July 21,1976 ) 